\title{
Impact of mission for integrated development of horticulture (MIDH) in Haryana
}

\author{
M Priyadarshini1, KK Kundu \& P Kumar
}

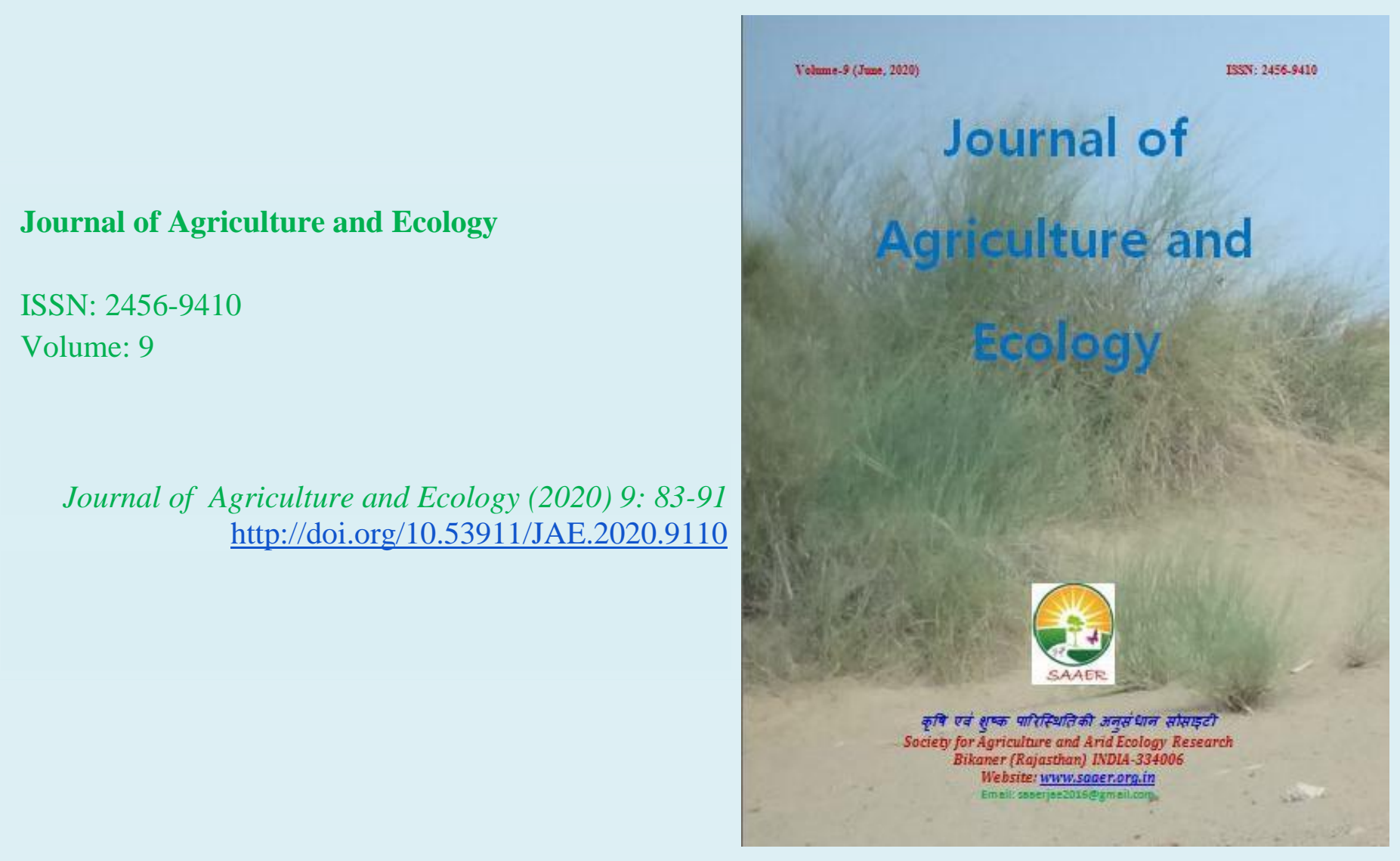




\title{
Impact of mission for integrated development of horticulture (MIDH) in Haryana
}

\author{
M Priyadarshini ${ }^{1} \square$, KK Kundu ${ }^{2} \&$ P Kumar $^{1}$
}

${ }^{1}$ Division of Agricultural economics, ICAR-IARI, Delhi, 110012

${ }^{2}$ Department of Agricultural Economics, CCSHAU, Hisar, Haryana

Mail id of corresponding author-

$\nabla$ Corresponding author: M Priyadarshini, mousumiecon23@gmail.com

\section{Article Info}

Article history

Received: 21 August 2020

Accepted: 30 August 2020

Available online: 04 September 2020

Key Words: CGR, NPV, IRR, B: C ratio, Payback period, MIDH.

\begin{abstract}
During the twelfth five-year plan govt of India has launched mission for integrated development of horticulture with effect from 2014-15 for holistic development of horticulture sector. Horticulture sector has emerged as an important source of farmer's income in Haryana and Kinnow is one of the most important and focused fruit crops under this scheme in Haryana. So, the study was carried out to analyse the trends in area, production and productivity of horticultural crops, to calculate the economics of kinnow and to identify the constraints faced by kinnow growers based on both primary and secondary data. Sirsa district of Haryana was selected as study area as it has highest area under cultivation of kinnow in the state. From the results a positive growth trend in horticulture sector was found. The CGR in area, production and productivity under total horticultural crops in Haryana from 2005-06 to 2017-18 was found to be of 5.08 per cent, 7.55 per cent and 2.34 per cent, respectively. The average total establishment cost, operational cost, NPV, IRR, B: C ratio and payback period for kinnow were found of Rs.122460, Rs. 56662, Rs.747703.64, 26.24 per cent and 7 years, respectively. Major constraints faced by fruits growers were as lack of infrastructure for processing and storage, inadequate infrastructure for post-harvest management, poor marketing facility, lack of good quality planting materials etc.
\end{abstract}

Copyright (O2020 Priyadarshini et al., This is an open access article published under the terms of the Creative Commons Attribution License, which permits unrestricted use, distribution, and reproduction in any medium, provided the original work is properly cited.

Preferred citation: Priyadarshini M, Kundu KK \& Kumar P. 2020. Impact of mission for integrated development of horticulture (MIDH) in Haryana. Journal of Agriculture and Ecology, 9: 83-91; http://doi.org/10.53911/JAE.2020.9110.

\section{Introduction}

In India the need for horticulture development was first time felt during the $4^{\text {th }}$ five-year plan, but during that time there was a need to increase the food grain production (Chand et al. 2008). Department of Agriculture, Cooperation and Farmers Welfare of Ministry of
Agriculture was the nodal agency for over viewing horticulture development in the country. Considering the importance of horticulture sector in 2011-12, government of India had announced 2012 as the "Year of Horticulture". During the $12^{\text {th }}$ five year plan 
Department of Agriculture, Co-operation and Farmers welfare has launched Mission for Integrated Development of Horticulture with effect from 2014-15 for wholistic development of horticulture sector by subsuming schemes like National Horticulture Mission (NHM), Horticulture Mission for North Eastern and Himalayan states (HMNEH), National Bamboo Mission (NBM), National Horticultural Board (NHB), Coconut Development board (CDB), Central Institute of Horticulture (CIH), Nagaland. The total outlay for development comprises share of central and states government in the ratio of 85:15 except for North Eastern and Himalayan states.

Haryana produced about 8091.71 thousand metric tones (MT) of horticulture produce from 534.01 thousand ha and accounted for 2.6 per cent of total horticultural production in the country (2017-18). The major share of horticulture produce comprises of vegetables $(88.4 \%)$ and fruits $(9.8 \%)$. The total fund allocated for MIDH in 2019-20 for Haryana is 183.33 crores with centre and state contribution of 110 crores and 73.33 crores, respectively. The focused crops under this programme include fruits (guava, kinnow, ber and aonla), vegetables (brinjal, cabbage, cauliflower, okra, onion, peas and potatoes) and flowers (rose, marigold, gerbera, etc). Horticulture sector has emerged as an important source of farmer's income in Haryana and Kinnow is one of the most important and focused fruit crops under this scheme in Haryana.

\section{Materials and Methods}

This study is based on both primary and secondary data. The primary data was collected from 30 kinnow growers from Sirsa district of Haryana as it shares maximum area under kinnow cultivation in the state. Secondary data related to area, production and productivity of total horticultural crops and citrus was collected from department of horticulture, Govt. of Haryana.

\section{Estimation of growth rate}

To calculate the trends in area, production and productivity of horticultural crops for a period of 13 years i.e. from 2005 to 2017, CGR was calculated by using the following formula.

$$
Y=A B^{t} U_{t}
$$

Taking $\log$ i.e.,

$$
\log Y=\log A+t \log B+\log U_{t}
$$

$$
\text { i.e. } \mathrm{y}=\mathrm{a}+\mathrm{bt}+\mathrm{u}_{\mathrm{t}}
$$

Where,

$\mathrm{y}=$ area or production or yield,

$\mathrm{a}=$ constant,

$b=$ regression coefficient,

$\mathrm{u}_{\mathrm{t}}=$ disturbance term

$\mathrm{t}=$ time in years starting from the base year 2005-06.

$\mathrm{CGR}=($ antilog b-1) $* 100$

\section{Costs and returns from kinnow orchard}

Establishment cost, operational cost and various economic tools like net present value (NPV), benefit cost ratio (B:C), internal rate of return (IRR), payback period was used.

\section{Depreciation and interest rate for fruits}

For estimating the annual cost, the depreciation has been worked out @ 4 per cent per annum of the fixed investment by applying straight line method or direct method, assuming the productive life as 25 years for kinnow. Further rate the interest has been taken@ 12 per cent per annum on operational cost. 


\section{Amortization of fixed cost}

Annual amortization on fixed cost was calculated using compound cost formula @12 per cent per annum by assuming 25 years as orchard life.

$$
I=B \frac{i}{1-(1+i)^{-n}}
$$

Where,

$$
\begin{aligned}
& \text { I = Annual cost, } \\
& \mathrm{B}=\text { Present fixed cost, } \\
& \mathrm{i}=\text { Interest rate }(12 \% \text { per annum), and } \\
& \mathrm{n}=\text { Economic life of the orchard (in } \\
& \text { years). }
\end{aligned}
$$$$
\mathrm{IRR}=\text { (lower (difference (Present worth of the cash flow at lower discount rate) }
$$$$
\text { discount }+ \text { between two } \mathrm{x}
$$$$
\text { rate) discount rates) }
$$

\section{Benefit cost ratio}

Ratio between the sum of discounted benefits of returns (R) and the sum of discounted cost $(K)$, i.e. $B=R / K$. If this ratio is greater than 1.00 then the investment in kinnow orchard is considered to be economically viable.

\section{Payback period}

It is the period within which the cost of the orchard is fully recovered from its own returns. In other words, it indicates the number of years by which the returns (R) equal, to the cost of orchard $(\mathrm{K})$. For this condition the following relationship must be satisfied. $\sum_{i=1}^{n} \mathrm{Ri}=\mathrm{K}$

Where, $\mathrm{i}=1,2,3 \ldots \ldots . \mathrm{n}$ year,

$\mathrm{R}=$ Indicates the return over a number of year,

\section{Net present value}

Future net returns were discounted to their net present value by using the following formula:

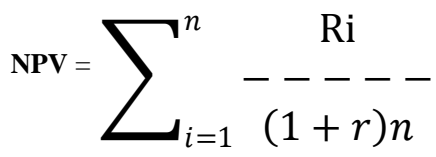

Where $\mathrm{R}_{\mathrm{i}}=$ returns from kinnow orchard in the $\mathrm{i}^{\text {th }}$ year

$$
i=\text { years of orchard life }=1,2 \ldots n
$$

\section{Internal rate of return}

Internal rate of return is the discounting rate which makes the NPV zero. So IRR was calculated using the following formula, cash flow at two discount rates)

$\mathrm{K}=$ The cost of orchard.

\section{Identification of constraints}

For identifying the production and marketing constraints faced by the farmers Henry Garrett ranking technique was used. The respondents were asked to rank the given constraints. The order of merit thus given by the respondents was converted in to ranks using the following formula

Percentage position $=\frac{100-\left(\mathrm{R}_{\mathrm{ij}}-0.5\right)}{\mathrm{N}_{\mathrm{j}}}$

Where, individual

$$
R_{i j}=\text { Rank given for ith item } j^{\text {th }}
$$

individual 


\section{Results and Discussion}

Trends in area, production and productivity of total horticultural crop and citrus in Haryana

From the Table 1 it is evident that the area, production and productivity of total horticultural crops and citrus are increasing over the years. The CGR in area, production and productivity for total horticultural crops was found to be 5.22 per cent, 7.97 per cent and 2.60 per cent per annum, respectively. Whereas the CGR in area, production and productivity of citrus was found to be 11.69 per cent, 17.67 per cent and 5.36 per cent per annum, respectively. It can be observed that after the implementation of National Horticulture Mission which is now subsumed under the MIDH area, production and productivity of horticultural crops has been significantly increased in Haryana. This study is in conformity with Kondal (2014), Tuteja (2011), Nabi et al. (2017) and Jha et al. (2019) Table 1. Trends in area, production and productivity of total horticultural crop and citrus in Haryana

\begin{tabular}{lcccccc}
\hline Years & \multicolumn{2}{c}{ Area ('000 ha) } & Production ('000MT) & \multicolumn{2}{c}{$\begin{array}{c}\text { Productivity } \\
\text { (tonnes/ha) }\end{array}$} \\
\cline { 2 - 7 } & $\begin{array}{c}\text { Total } \\
\text { horticultural } \\
\text { crop }\end{array}$ & Citrus & $\begin{array}{c}\text { Total } \\
\text { horticultural } \\
\text { crop }\end{array}$ & Citrus & $\begin{array}{c}\text { Total } \\
\text { horticultural } \\
\text { crop }\end{array}$ & Citrus \\
& 277.40 & 5.04 & 3292.40 & 69.56 & 11.87 & 13.80 \\
$2005-06$ & 320.40 & 8.21 & 3618.00 & 66.84 & 11.29 & 8.14 \\
$2007-08$ & 354.70 & 13.84 & 4386.70 & 98.33 & 12.37 & 7.11 \\
$2011-12$ & 424.70 & 17.66 & 5671.94 & 214.17 & 13.36 & 12.12 \\
$2013-14$ & 448.10 & 19.38 & 6285.50 & 235.35 & 14.00 & 12.14 \\
$2015-16$ & 494.20 & 19.65 & 7053.84 & 301.76 & 14.27 & 15.36 \\
$2017-18$ & 555.89 & 20.83 & 9117.52 & 335.82 & 16.40 & 16.13 \\
\hline Percentage change & 92.50 & 313.13 & 145.77 & 382.29 & 27.66 & 16.86 \\
over 2005-06 & & & & & & 5.36 \\
CGR (\%p.a.) & 5.22 & 11.69 & 7.97 & 17.67 & 2.60 & 5.36 \\
\hline
\end{tabular}

(Source: Department of Horticulture, Govt. of Haryana)

Establishment cost of Kinnow orchard in Sirsa district of Haryana

The total establishment cost of kinnow orchard was found to be of Rs.1,22,460 per hectare in Sirsa district of Haryana. The major component of establishment costs was Construction of pond (35.59\%), Drip irrigation (19.23\%), Permanent fencing (10.24\%), Preparation of land and lay out
(5.71\%) and Cost of plant (5.19\%). Gangwar et al. (2005), Gangwar and Singh (1998) and Bhat et al. (2011) have also found similar kind of results.

Table 2. Establishment cost of kinnow in Haryana

\begin{tabular}{lcc}
\hline Particulars & $\begin{array}{c}\text { Value (Rs./ } \\
\text { hectare) }\end{array}$ & Percentage \\
\hline Preparation of land & 6987 & 5.71
\end{tabular}




\section{Journal of Agriculture and Ecology, 2020, Vol. 9, 83-91 \\ http://saaer.org.in}

\begin{tabular}{|c|c|c|c|c|c|c|c|c|c|}
\hline \multicolumn{5}{|c|}{ and lay out } & \multicolumn{3}{|c|}{ Permanent fencing } & 12543 & 10.24 \\
\hline \multirow{2}{*}{\multicolumn{2}{|c|}{$\begin{array}{l}\text { Digging and filling } \\
\text { of pits }\end{array}$}} & \multirow{2}{*}{\multicolumn{2}{|c|}{5343}} & 4.36 & \multirow{2}{*}{\multicolumn{3}{|c|}{$\begin{array}{l}\text { Cost of equipment } \\
\text { Miscellaneous }\end{array}$}} & 5874 & 4.80 \\
\hline & & & & & & & & 2387 & 1.95 \\
\hline \multicolumn{2}{|c|}{ Cost of irrigation } & \multicolumn{2}{|c|}{1051} & 0.86 & \multicolumn{3}{|c|}{ Total } & 122460 & 100.00 \\
\hline \multicolumn{2}{|c|}{ Cost of plant } & \multicolumn{2}{|c|}{6358} & 5.19 & \multicolumn{5}{|c|}{ Operational cost of kinnow orchard } \\
\hline \multicolumn{2}{|c|}{$\begin{array}{l}\text { Cost of } \\
\text { replacement plant }\end{array}$} & \multicolumn{2}{|l|}{965} & 0.79 & \multirow{6}{*}{\multicolumn{5}{|c|}{$\begin{array}{l}\text { The operational cost of kinnow orchard } \\
\text { increases from } 1^{\text {st }} \text { year to } 7^{\text {th }} \text { year of orchard } \\
\text { establishment. After } 7^{\text {th }} \text { years onwards the per } \\
\text { hectare operational cost becomes more or less } \\
\text { stabilised. In the } 7^{\text {th }} \text { year the per hectare } \\
\text { operational cost was found to be } \square 75625 \text {. The } \\
\text { major components or operational cost are cost } \\
\text { of plant protection }(20.48 \%) \text {, cost of pruning } \\
\text { and cutting }(13.65 \%) \text {, cost of intercultural } \\
\text { operations }(12.37 \%) \text {, cost of watch and ward } \\
(12.23 \%) \text { and cost of irrigation }(11.86 \%) \text {. }\end{array}$}} \\
\hline \multicolumn{2}{|c|}{ Manures and } & \multicolumn{2}{|c|}{4737} & 3.87 & & & & & \\
\hline $\begin{array}{l}\text { Trans } \\
\text { plant }\end{array}$ & ortation of & \multicolumn{2}{|l|}{4659} & 3.80 & & & & & \\
\hline Plant & ion cost & \multicolumn{2}{|c|}{2963} & 2.42 & & & & & \\
\hline $\begin{array}{l}\text { Inter } \\
\text { opera }\end{array}$ & $\begin{array}{l}\text { ltural } \\
\text { on }\end{array}$ & \multicolumn{2}{|c|}{1469} & 1.20 & & & & & \\
\hline $\begin{array}{l}\text { Cons } \\
\text { pond }\end{array}$ & uction & \multicolumn{2}{|c|}{43578} & 35.59 & & & & & \\
\hline \multicolumn{2}{|c|}{ Drip irrigation } & \multicolumn{2}{|c|}{23546} & \multicolumn{6}{|l|}{19.23} \\
\hline \multicolumn{10}{|c|}{ Table 3. Operational cost of kinnow orchard in Haryana } \\
\hline \multirow{2}{*}{\multicolumn{2}{|c|}{$\begin{array}{cl}\text { S. } & \text { Particulars } \\
\text { No. } & \end{array}$}} & \multicolumn{8}{|c|}{ Years } \\
\hline & & 1 & 2 & 3 & 4 & 5 & 6 & $\begin{array}{l}7^{\text {th }} \text { and } \\
\text { onwards }\end{array}$ & $\begin{array}{l}\text { Percentage in } \\
\text { total cost of } \\
\text { orchard in the } \\
7^{\text {th }} \text { year }\end{array}$ \\
\hline 1 & $\begin{array}{l}\text { Manure and } \\
\text { fertilizer }\end{array}$ & 3127 & 3758 & 4523 & 5568 & 6894 & 7164 & 7367 & 9.74 \\
\hline 2 & $\begin{array}{l}\text { Plant } \\
\text { protection } \\
\text { insecticides, } \\
\text { pesticides }\end{array}$ & 8756 & 11503 & 12654 & 13569 & 14568 & 15102 & 15489 & 20.48 \\
\hline 3 & $\begin{array}{l}\text { Pruning and } \\
\text { cutting }\end{array}$ & & 3781 & 6873 & 9245 & 9741 & 9964 & 10324 & 13.65 \\
\hline 4 & $\begin{array}{l}\text { Intercultural } \\
\text { and hoeing }\end{array}$ & 4847 & 5468 & 6631 & 7863 & 8521 & 9253 & 9352 & 12.37 \\
\hline 5 & $\begin{array}{l}\text { Irrigation } \\
\text { cost }\end{array}$ & 4498 & 5120 & 5961 & 7546 & 8276 & 8791 & 8967 & 11.86 \\
\hline 6 & $\begin{array}{l}\text { Replacement } \\
\text { and casualty }\end{array}$ & 1437 & 1654 & 2145 & 2754 & 3124 & 3396 & 3758 & 4.97 \\
\hline 7 & $\begin{array}{l}\text { Watch and } \\
\text { ward }\end{array}$ & 4987 & 5489 & 6124 & 6717 & 7813 & 8703 & 9247 & 12.23 \\
\hline 8 & Staking & 0 & 0 & 0 & 7500 & 7800 & 8192 & 8175 & 10.81 \\
\hline 9 & Miscellaneous & 1724 & 1923 & 2149 & 2465 & 2563 & 2785 & 2946 & 3.90 \\
\hline & $\begin{array}{l}\text { Total } \\
\text { operational } \\
\text { cost }\end{array}$ & 29376 & 38696 & 47060 & 63227 & 69300 & 73350 & 75625 & 100 \\
\hline
\end{tabular}


Costs and returns from kinnow orchard in Haryana

The costs and returns from kinnow orchard are given in Table 4. The total cost was calculated after adding the rental value of land, amortized fixed cost, operational cost, depreciation and interest on working capital. The first 3 years of orchard establishment are the lean periods as no production was seen during these years. The production started increasing from $4^{\text {th }}$ years and becomes constant after $7^{\text {th }}$ year of orchard establishment. Even after considering the returns from inter cropping the farmer has to bear a loss up to $5^{\text {th }}$ year of orchard life. The net return was found positive in the $6^{\text {th }}$ year. In the $7^{\text {th }}$ year the net return was found to be Rs.257397. This return remains same for the coming years of orchard life.

Table 4. Costs and returns from kinnow orchard in Haryana

\begin{tabular}{|c|c|c|c|c|c|c|c|}
\hline \multirow[t]{2}{*}{ Particulars } & \multicolumn{7}{|c|}{ Years } \\
\hline & 1 & 2 & 3 & 4 & 5 & 6 & $\begin{array}{c}7^{\text {th }} \text { and } \\
\text { onwards }\end{array}$ \\
\hline $\begin{array}{l}\text { Rental value } \\
\text { of land } \\
\text { Amortized }\end{array}$ & 44256 & 47234 & 48563 & 49671 & 52874 & 55963 & 58796 \\
\hline $\begin{array}{l}\text { fixed cost } \\
\text { Operational }\end{array}$ & 15614 & 15614 & 15614 & 15614 & 15614 & 15614 & 15614 \\
\hline cost & 29376 & 38696 & 47060 & 63227 & 69300 & 73350 & 75625 \\
\hline $\begin{array}{l}\text { Expected } \\
\text { depreciation } \\
\text { on Fixed Cost } \\
\text { investment } \\
\text { @ } 4 \%\end{array}$ & 4898 & 4898 & 4898 & 4898 & 4898 & 4898 & 4898 \\
\hline $\begin{array}{l}\text { Interest on } \\
\text { operational } \\
\text { cost @ } 12 \%\end{array}$ & & & & & & & \\
\hline $\mathrm{PA}$ & 3525 & 4644 & 5647 & 7587 & 8316 & 8802 & 9075 \\
\hline $\begin{array}{l}\text { Total Cost (1- } \\
5)\end{array}$ & 97670 & 111086 & 121782 & 140997 & 151002 & 158627 & 164008 \\
\hline $\begin{array}{l}\text { Production } \\
\text { (qtls) }\end{array}$ & 0 & 0 & 0 & 43 & 79 & 207 & 311 \\
\hline $\begin{array}{l}\text { Price (Rs. per } \\
\text { qtls) }\end{array}$ & 0 & 0 & 0 & 1043 & 1148 & 1292 & 1355 \\
\hline Gross returns & 0 & 0 & 0 & 44849 & 90692 & 267444 & 421405 \\
\hline Net returns & -97670 & -111086 & -121782 & -96148 & -60310 & 108817 & 257397 \\
\hline $\begin{array}{l}\text { Return from } \\
\text { inter cropping }\end{array}$ & 28974 & 25463 & 24151 & 24080 & 19654 & 0 & 0 \\
\hline $\begin{array}{l}\text { Total net } \\
\text { returns }\end{array}$ & -68696 & -85623 & -97631 & -72068 & -40656 & 108817 & 257397 \\
\hline
\end{tabular}


NPV was found to be Rs. 747703.64. This NPV is a high positive value which is showing
This study is in conformity with Kumar et al. (2017), Kaur and Singla (2016).

Table 5. Net present value of kinnow orchard in Haryana

\begin{tabular}{lccccc}
\hline Year & $\begin{array}{c}\text { Negative } \\
\text { returns } \\
\text { (Rs.) }\end{array}$ & $\begin{array}{c}\text { Positive } \\
\text { returns } \\
\text { (Rs.) }\end{array}$ & $\begin{array}{c}\text { Discounting } \\
\text { factor 1/(1+i) }\end{array}$ & $\begin{array}{c}\text { Present value } \\
\text { Negative } \\
\text { returns (Rs.) }\end{array}$ & $\begin{array}{c}\text { Positive } \\
\text { returns (Rs.) }\end{array}$ \\
\hline 1 & 68696 & & 0.8929 & 61335.29 & \\
2 & 85623 & & 0.7972 & 68257.75 & \\
3 & 97631 & & 0.7118 & 69491.96 & \\
4 & 72068 & & 0.6355 & 45800.52 & \\
5 & 40656 & & 0.5674 & 23069.31 & 55130.08 \\
6 & & 108817 & 0.5066 & & 960528.38 \\
7 to 25 & & 257397 & 3.7317 & & 1015658.46 \\
\hline Total & 364673 & 366214 & & 267954.82 & \\
\hline
\end{tabular}

$\mathrm{NPV}=1015658.46-267954.82=747703.64$

Internal rate of return of kinnow orchard

In the present study various discounting rates were taken to obtain the net present value zero or a minimum one. Finally, the internal rate of return was found to be a higher value of 26.24 per cent per annum which is higher than the prevailing interest rate of 12 per cent, indicating high profitability of kinnow orchard in Haryana.

Table 6. Internal rate of return of kinnow orchard in Haryana

\begin{tabular}{|c|c|c|c|c|c|}
\hline Year & $\begin{array}{l}\text { Net cash } \\
\text { flow } \\
\text { (Rs.) }\end{array}$ & $\begin{array}{c}\text { Present Value } \\
\text { Coefficient } \\
\mathrm{r}=26 \% \\
{\left[1 /(1+\mathrm{r})^{\mathrm{n}}\right]}\end{array}$ & $\begin{array}{c}\text { Corresponding } \\
\text { Value } \\
\text { (Rs.) }\end{array}$ & $\begin{array}{c}\text { Present Value } \\
\text { Coefficient } \\
\mathrm{r}=27 \% \\
{\left[1 /(1+\mathrm{r})^{\mathrm{n}}\right]}\end{array}$ & $\begin{array}{c}\text { Corresponding } \\
\text { Value } \\
\text { (Rs.) }\end{array}$ \\
\hline 1 & -68696 & 0.7937 & -54520.25 & 0.8333 & -57246.27 \\
\hline 2 & -85623 & 0.6299 & -53932.05 & 0.6944 & -59460.08 \\
\hline 3 & -97631 & 0.4999 & -48806.42 & 0.5787 & -56499.54 \\
\hline 4 & -72068 & 0.3968 & -28593.04 & 0.4823 & -34755.02 \\
\hline 5 & -40656 & 0.3149 & -12801.83 & 0.4019 & -16338.73 \\
\hline 6 & 108817 & 0.2499 & 27194.02 & 0.3349 & 36442.59 \\
\hline 7 to 25 & 257397 & 0.9493 & 244346.97 & 1.6221 & 417523.67 \\
\hline Total & & & 72887.41 & & 229666.63 \\
\hline
\end{tabular}

$\mathrm{IRR}=26+1(72887.41) /(72887.41+229666.63)=26.24$

$B: C$ ratio and payback period of kinnow orchard

In the prevailing interest rate of 12 per cent the $\mathrm{B}: \mathrm{C}$ ratio was found to be 1:3.79 which implies that for every Rs.1 investment in kinnow orchard the farmer is going to have a return of Rs.3.79 rupees. The payback period of kinnow orchard was found to be 7 
years which means the costs were recovered in $7^{\text {th }}$ year of orchard establishment. This result is in conformity with Gangwar et al. (2005), Gangwar \& Singh (1998).

\section{Constraints faced by the kinnow growers}

Major constraints faced by the MIDH beneficiary kinnow growers are lack of provision of infrastructure for processing and storage, lack of availability of good quality planting materials, lack of assistance for protected cultivation for nursery, lack of assistance for integrated post-harvest management and inadequate assistance for creation of water resources. Kumar et al. 2004 and Mittal, 2007 also found lack of assistance for infrastructure and post-harvest management as the major constraints faced by the Indian farmers

Table 6. Ranking of constraints incurred in kinnow cultivation through Garrett ranking in Haryana

\begin{tabular}{lccc}
\hline Constraints & $\begin{array}{c}\text { Total } \\
\text { score }\end{array}$ & $\begin{array}{c}\text { Average } \\
\text { score }\end{array}$ & Rank \\
\hline Lack of provision of infrastructure like processing and storage & 1844 & 61.47 & I \\
Lack of availability of good quality planting material & 1830 & 61.00 & II \\
Lack of assistance for protected cultivation for nursery & 1709 & 56.97 & III \\
Lack of assistance for integrated post-harvest management & 1700 & 56.67 & IV \\
Inadequate assistance for creation of water resources & 1519 & 50.63 & V \\
Inadequate facility for rejuvenation with improved cultivars & 1434 & 47.80 & VI \\
Lack of assistance for organic farming & 1390 & 46.33 & VII \\
Inadequate scope for horticulture mechanization & 1323 & 44.10 & VIII \\
Poor marketing facility & 1222 & 40.73 & IX \\
Lack of promotion of INM and IPM & 1029 & 34.30 & X \\
\hline
\end{tabular}

\section{Conclusion}

The CGR in area, production and productivity of total horticultural crops in Haryana was found to be of 5.08 per cent, 7.55 per cent and 2.34 per cent, respectively. A positive growth trend was found in growth of horticulture sector after implementation of this scheme. The average total establishment cost, operational cost, NPV, IRR, B: C ratio and payback period for kinnow were found of Rs.122460, Rs.56662, Rs.747703.64, 26.24 per cent and 7 years, respectively. Major constraints faced by fruits growers were as lack of infrastructure for processing and storage, inadequate infrastructure for postharvest management, poor marketing facility, lack of good quality planting materials etc. Keeping in view the high profitability and constraints it can be suggested to the government to focus more on infrastructural facilities for post-harvest management, marketing facility. Early maturing and quality planting materials of fruit varieties should be made available to the farmers to get higher prices for sale in the market. Arrangements for export of the product should be made in such a way that it can be made available to the destination of sale within a short period. India can emerge as a far bigger producer and exporter if sufficient emphasis is given to resource allocation, infrastructure development, more R\&D, technological 
upgradation and better policy framework for horticulture sector. Horticulture sector with strong forward and backward linkages as an organized industry can stimulate and sustain growth.

\section{References}

Bhat, A., Kachroo, J. and Kachroo, D. (2011) Economic appraisal of kinnow Production and its marketing under North- Western Himalayan Region of Jammu. Agricultural Economics Research Review, 24(2): 283-290.

Chand, R., Raju, S.S. and Pandey, L.M. (2008). Progress and Potential of Horticulture in India.Indian Journal of Agricultural Economics, 63(3):299-309.

Gangwar, L. S. and Singh, S. (1998). Economic evaluation of Nagpur mandarin cultivation in Vidarbha region of Maharashtra. Indian Journal of Agricultural Economics, 53(4): 648-653.

Gangwar LS, Ilyas SM, Singh D \& Kumar S. 2005. An economic evaluation of kinnow mandarin cultivation in Punjab. Agricultural Economics Research Review, 18(1): 71-80.

Jha GK, Suresh A, Punera B \& Supriya P. 2019. Growth of horticulture sector in India: Trends and prospects. Indian Journal of Agricultural Sciences, 89 (2): 314-321.
Nabi T \& Bagalkoti ST. 2017. Growth trends of horticulture crops in India. International Journal of Multidisciplinary Research and Development, 4(3): 158-164.

Kaur M \& Singla N. 2016. An economic analysis of kinnow cultivation and marketing in Fazilka district of Punjab. Indian Journal of Economics and Development, 12(4):711-718.

Kumar N, Duhan A, Bhatia J \& Malik V. 2018. Economic appraisal of kinnow production and its marketing in Sirsa District of Haryana, India. International Journal of Current Microbiology and Applied Sciences, 6(11): 4045-4053.

Kumar S, Joshi PK \& Pal S. 2004. Impact of Vegetable Research in India. NCAP Workshop Proceedings No.13. National Centre for Agricultural Economics and Policy Research, New Delhi.

Kondal K. 2014. Trends in area and production of horticulture sector in India. ANVESAK Journal, 44(2), 1-11.

Mittal S. 2007. Strengthening backward and forward linkages in horticulture: Some successful initiatives. Agricultural Economics Research Review, 20 (Conf. Issue): 457-469. 